\title{
Familial hyperthyroidism due to mutations in TSH receptor
}

INSERM

\section{Source}

INSERM. (1999). Orphanet: an online rare disease and orphan drug data base. Familial hyperthyroidism due to mutations in TSH receptor. ORPHA:424

Familial non-autoimmune autosomal dominant hyperthyroidism (FNAH) is a rare hyperthyroidism (see this term) characterized by mild to severe hyperthyroidism, presence of goiter, absence of features of autoimmunity, frequent relapses while on treatment and a positive family history. 